\title{
Acetaldehyde emission from wood induced by the addition of ethanol
}

\author{
Shin-ichiro Tohmura $\cdot$ Atsuko Ishikawa \\ Kohta Miyamoto $\cdot$ Akio Inoue
}

Received: 1 July 2011/Accepted: 19 August 2011/Published online: 27 December 2011

(C) The Japan Wood Research Society 2011

\begin{abstract}
A mechanism of acetaldehyde emission from wood induced by the addition of ethanol was proposed. It is known that acetaldehyde generation is due to the oxidation of ethanol via a metabolic process involving alcohol dehydrogenase (ADH) in living bodies. However, it remains unclear whether the enzymatic alcohol oxidation is applicable to wood. We investigated possible factors of wood parts, conditioning, storage sites, and heating and sterilization treatments on acetaldehyde emission using the syringe method and HPLC analysis. We reconfirmed that acetaldehyde emission was observed only when ethanol was added to wood. Greater acetaldehyde emissions were obtained in heartwood compared to sapwood in both Japanese cedar (Cryptomeria japonica D. Don) and Japanese cypress (Chamaecyparis obtusa Endl.) specimens. In addition, an acetaldehyde conversion rate of $1-2 \mathrm{~mol} \%$ was determined in green cedar heartwood samples, while, conversely, airdried cedar heartwood samples showed 4-5 mol\%. Ethylene oxide gas sterilization had the effect of decreasing acetaldehyde emission on air-dried wood, but not on green wood. Autoclave sterilization could completely prevent acetaldehyde emissions from both green and air-dried wood. These results suggested that an original $\mathrm{ADH}$ in wood and an attached ADH from the outside via microorganisms onto wood were assumed to be the primary causes of acetaldehyde emissions from wood induced by the addition of ethanol.
\end{abstract}

Parts of this study were presented at the 58th Annual Meeting of the Japan Wood Research Society, Tsukuba, March 2008, and at BIOCOMP 2010, Banff, October 2010.

S. Tohmura $(\bowtie) \cdot A$. Ishikawa $\cdot$ K. Miyamoto $\cdot$ A. Inoue

Forestry and Forest Products Research Institute,

Tsukuba 305-8687, Japan

e-mail: tomura@ffpri.affrc.go.jp
Keywords Acetaldehyde - Emission - Ethanol - ADH · Sterilization

\section{Introduction}

Acetaldehyde is one of the metabolic intermediates in humans, many other animals and higher plants, as well as a product of alcohol fermentation. It has been identified in foods, beverages, cigarette smoke and vehicle exhausts, as well as while burning gas, fuel, oil and coal [1, 2]. Conversely, acetaldehyde is ranked as Group 2B, possibly carcinogenic, for human carcinogenicity by the International Agency for Research on Cancer [3]. It is also listed in the guidelines of indoor air quality in Japan as a harmful chemical substance for human health [4]. According to the government survey of indoor air quality for newly constructed houses in Japan from 2002 to 2005 [5], levels of acetaldehyde exceeding the guideline value $\left(48 \mu \mathrm{g} / \mathrm{m}^{3}\right)$ were detected in about $10 \%$ of all newly constructed houses. However, the origin of acetaldehyde emission in indoor air remains unclear. In the survey, as wooden houses showed higher acetaldehyde values compared to non-wooden houses, wood materials were suspected as a major origin of acetaldehyde emission in houses [5]. Furthermore, several papers reported that some glued laminated timbers showed extraordinarily large acetaldehyde emissions [6-10]. We tried to elucidate the origin of acetaldehyde emission from glued laminated timbers and found that ethanol used as a partial solvent in phenol-resorcinol-formaldehyde resin adhesives caused the acetaldehyde emission [11]. This means that the interaction between ethanol and wood became a trigger for acetaldehyde emission from wood materials.

Acetaldehyde production by ethanol oxidation involving alcohol dehydrogenase (ADH) is well known as a typical 
metabolic process of alcohol in a living organism. Several papers reported that ethanol and ADH were present in the leaves and stems of trees, and acetaldehyde resulted in the oxidation of ethanol emitted from leaves into the atmosphere [12-17]. However, it remains unclear whether the enzymatic alcohol oxidation mechanism is adoptable in the case of wood. Kurosaki et al. [18] showed important evidence of the enzymatic mechanism by ADH. They found that softwood powder had much more interaction with ethanol than hardwood powder. They also used various alcohols for Japanese cedar powder and elucidated that rather than methanol and 2-propanol, ethanol and 1-propanol could produce each corresponding oxidation product, namely, acetaldehyde and propionaldehyde. ADH enzymes were confirmed to be located in a vascular cambium in trees as well as in leaves $[13,15]$. Therefore, ADH is very likely to remain in wood after harvest.

In the present study, we investigated some factors related to the essential requirements of acetaldehyde emissions from wood induced by the addition of ethanol.

\section{Materials and methods}

\section{Materials}

Wood samples used in the study were 42- and 43-year-old Japanese cedar (Cryptomeria japonica D. Don) trees, namely $\mathrm{A}$ and B, and 74- and 87-year old Japanese cypress (Chamaecyparis obtusa Endl.) trees, namely $\mathrm{C}$ and D. They were harvested in a forest in Tochigi, Japan. After harvesting, the fresh logs were placed indoors for about 1 month at ambient temperature and moisture, before being subsequently cut into small blocks, $20(\mathrm{~T}) \times 20(\mathrm{R}) \times 10(\mathrm{~L}) \mathrm{mm}$ as shown in Fig. 1a, from individual wood parts: sapwood and heartwood

(a) Sample size and ethanol addition
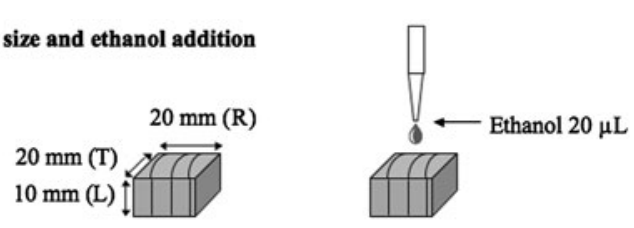

(b) Setting

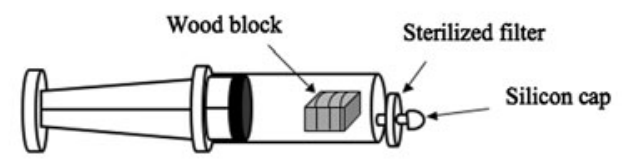

(c) Air-sampling

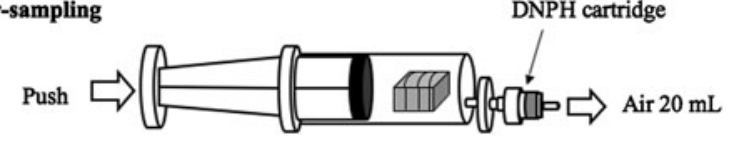

Fig. 1 Wood sample preparation and the air sampling method using disposable sterilized plastic syringe for both cedar and cypress, and the transition zone (white zone) for cedar alone. A filter paper (No. $1240 \varnothing \mathrm{mm}$, Advantec Toyo Kaisha Ltd., Tokyo, Japan) measuring $20 \times 20 \mathrm{~mm}$ was used as a base-material control.

\section{Storage condition}

Each specimen was divided into three groups. The first was placed under a rooftop in the open air for 2 weeks (outside group). The second group was placed in a laboratory under ambient conditions for 2 weeks (room group). The third group was placed in a stainless $20 \mathrm{~L}$ chamber system equipped with a clean air ventilation system (ADPAC system, ADTEC Co., Yokohama, Japan). The chamber was kept at a constant temperature of $28^{\circ} \mathrm{C}$, relative humidity of $50 \%$ and air ventilation of 0.5 times/h for 2 weeks (chamber group). Each experiment was repeated three times.

\section{Heating treatment}

Part of the Japanese cedar-block specimens of A and B was placed in the above-mentioned chamber at $28^{\circ} \mathrm{C}$ for 2 weeks. The other specimens were heated in an oven (DKN302, Yamato Scientific Co. Ltd., Tokyo) at $90^{\circ} \mathrm{C}$ for 50 or $90 \mathrm{~min}$. This experiment was performed five or six times under identical conditions.

\section{Sterilization treatment}

Three individual 25-year old Japanese cedar trees, namely E, F and G, were harvested in an experiment forest of the Forestry and Forest Products Research Institute in Ibaraki prefecture, Japan. Each heartwood part was cut into small blocks, $20(\mathrm{~T}) \times 20(\mathrm{R}) \times 10(\mathrm{~L}) \mathrm{mm}$. Half the samples were used right after cutting as green wood without further treatment, and the remaining half were used as air-dried wood in a conditioning room for 2 weeks to reach an airdried state.

Parts of both green and air-dried wood block samples were sterilized by two sterilization methods. One is autoclave sterilization treatment using the autoclave sterilizers system (HA-300MII, HIRAYAMA Manufacturing Co., Saitama, Japan). Ten pieces of wood block samples were enveloped in a self-sealing sterilization pouch $(9 \times 23 \mathrm{~cm}$, CROSSTEX, NY, USA), set in the chamber and then autoclave heated to $120^{\circ} \mathrm{C}$ under a steaming condition. Following the autoclave treatment for $2 \mathrm{~h}$, the pouch was removed from the chamber.

Another is ethylene oxide gas (EOG) sterilization treatment using a sterilizer (YS-A-C64E, YUYAMA Co., Osaka, Japan). Five pieces of wood block samples were enveloped in the sterilization pouch and placed in the EOG sterilizer. The air in the chamber was vacuumed, whereupon 
EOG was induced in the vessel. The chamber was kept at $30^{\circ} \mathrm{C}$ for $24 \mathrm{~h}$. After the treatment, EOG was completely exhausted, whereupon the pouch was removed; confirming the EOG had been processed by a color indicator on the pouch. Each experiment was repeated five times.

\section{Ethanol addition}

For half the samples under each identical condition, $20 \mu \mathrm{L}$ of distilled ethanol was carefully dropped onto the surface of wood samples with a micropipette and evenly spread as shown in Fig. 1a.

\section{Syringe measuring method}

Each specimen was enclosed in a $50-\mathrm{mL}$ disposable sterilized plastic syringe (SS-50ESZ, TERUMO CO., Tokyo, Japan) as shown in Fig. 1b. The injection tip of the syringe was covered with a sterilized $0.25-\mu \mathrm{m}$ filter (CS020AS, Advantec Toyo Kaisha Ltd., Tokyo, Japan) and sealed with a silicon cap. The air volume in the syringe was initially set to $50 \mathrm{~mL}$. All procedures for packing the samples into the syringes were carried out under a clean bench. The sealed syringes were placed in a conditioning dry chamber at $30^{\circ} \mathrm{C}$ for $24 \mathrm{~h}$, whereupon $20 \mathrm{~mL}$ of air in the syringe was pushed out through a 2,4-dinitrophenylhydrazine (DNPH) cartridge (GL-Pak mini AERO DNPH, GL Sciences Inc., Tokyo, Japan) attached to the tip of the syringe instead of a silicon cap as shown in Fig. 1c.

\section{Determination of acetaldehyde}

The DNPH derivatives in the cartridge were dissolved and diluted with high performance liquid chromatography (HPLC)-grade acetonitrile into a volumetric flask up to $5 \mathrm{~mL}$. Twenty-microliters of the DNPH derivative solution was then injected into a SHIMADZU, SIL-AD10vp HPLC system. HPLC separations were achieved on two ODS columns (STR-ODS II, $150 \mathrm{~mm} \times 4.6 \mathrm{~mm}$ I.D., Shinwa Chemical Industries, Ltd., Kyoto, Japan) The temperature of the column chamber in the HPLC system was maintained at $40^{\circ} \mathrm{C}$. A solvent gradient flowing at $1.0 \mathrm{~mL} / \mathrm{min}$ was provided. For the first $5 \mathrm{~min}$ of the gradient program, the solvent was acetonitrile/distilled water 40/60. The acetonitrile content increased linearly to $100 \%$ during the next $25 \mathrm{~min}$ of the program and remained at $100 \%$ for $5 \mathrm{~min}$. The acetonitrile/distilled ratio then reverted to $40 / 60$ for the next $1 \mathrm{~min}$ and remained at this level until the end of the 50-min analysis. The wave range of the UV detector in the HPLC system was set at $360 \mathrm{~nm}$. The amount of acetaldehyde was determined by the standard 13 carbonyl compounds (SUPELCO, CARB 1004 DNPH Mix2, SIGMA-ALDRICH, MO, USA). Moreover, the amount of acetaldehyde in the air of syringe was calculated using the following equation:

$$
\begin{aligned}
& \text { Acetaldehyde in the air of syringe }(\mu \mathrm{g}) \\
& =\text { Acetaldehyde determined by HPLC } \\
& \quad \times\left(V_{\text {Syringe }}-V_{\text {Sample }}\right) / V_{\text {Air }}
\end{aligned}
$$

where $V_{\text {Syringe }}$ is the initial syringe volume $\left(50 \mathrm{~cm}^{3}\right), V_{\text {Air }}$ is the volume of sampling air $\left(20 \mathrm{~cm}^{3}\right)$, and $V_{\text {Sample }}$ is the sample volume (for example: $4 \mathrm{~cm}^{3}$ for wood block samples).

\section{Results and discussion}

Influence of wood parts on acetaldehyde emission

Table 1 shows the average value of acetaldehyde in the syringe air after incubation at $30^{\circ} \mathrm{C}$ for $24 \mathrm{~h}$. The average value was calculated from the data of three identical conditions. There was almost no positive detection for all control wood samples and filter paper samples without ethanol, regardless of the different wood species, wood parts and storage conditions. On the contrary, the ethanol addition samples showed acetaldehyde emission except for the blank and filter paper control samples. It was reconfirmed that the interaction between ethanol and wood produced acetaldehyde as we found previously [11]. The reason for acetaldehyde emission is attributed to the addition of ethanol to wood, although the natural oxidation of ethanol in air is another possible explanation. However, this is unlikely because no acetaldehyde emission was observed in the blank and filter paper samples. It is thus safe to say that wood is an inevitable matrix of a conversion reaction from ethanol to acetaldehyde. In general, it is well known that acetaldehyde production occurs by an ADH action caused by a metabolic process in the human body following the intake of alcohol [1]. Researchers have revealed that ethanol and $\mathrm{ADH}$ existed in leaves and stems in living trees and produced acetaldehyde [12-17]. Therefore, it is most likely that the acetaldehyde conversion from ethanol was induced by ADH action, even in wood as well. The effect of the ADH activation was assured in the experiment using an enzymatic hindrance substance for wood powder by Kurosaki et al. [18]. They concluded that the ADH would act in wood and produce acetaldehyde from added ethanol.

In the series of ethanol-added samples, Fig. 2 shows the conversion rate $(\mathrm{mol} \%)$ calculated from the amounts of added ethanol. The converted acetaldehyde value of Japanese cedar heartwood was highest at $3 \mathrm{~mol} \%$. Japanese cedar showed greater acetaldehyde conversion than Japanese cypress for heartwood, but less for sapwood. In particular, the cypress D sapwood sample showed slightly more acetaldehyde conversion than the others in sapwood. 
Table 1 The effects of wood part and storage place on the average value of acetaldehyde $(\mu \mathrm{g})$ in the air of syringe at $30^{\circ} \mathrm{C}$ for $24 \mathrm{~h}$ after setting

\begin{tabular}{|c|c|c|c|c|c|c|c|c|c|c|c|}
\hline \multirow[t]{4}{*}{ Sample } & \multirow[t]{4}{*}{ Part } & \multirow[t]{4}{*}{ ID } & \multicolumn{9}{|c|}{ Acetaldehyde $(\mu \mathrm{g})^{\mathrm{a}}$} \\
\hline & & & \multicolumn{3}{|l|}{ Control } & \multicolumn{6}{|c|}{ Ethanol addition } \\
\hline & & & \multirow{2}{*}{$\begin{array}{l}\text { Chamber } \\
\text { Avg }\end{array}$} & \multirow{2}{*}{$\begin{array}{l}\text { Room } \\
\text { Avg }\end{array}$} & \multirow{2}{*}{$\begin{array}{l}\text { Outside } \\
\text { Avg }\end{array}$} & \multicolumn{2}{|c|}{ Chamber } & \multicolumn{2}{|l|}{ Room } & \multicolumn{2}{|c|}{ Outside } \\
\hline & & & & & & Avg & SD & Avg & SD & Avg & SD \\
\hline Blank & - & - & $<0.1^{\mathrm{b}}$ & $<0.1$ & $<0.1$ & $<0.1$ & - & $<0.1$ & - & $<0.1$ & - \\
\hline Filter paper & - & - & $<0.1$ & $<0.1$ & $<0.1$ & 0.1 & 0.0 & 0.1 & 0.1 & $<0.1$ & - \\
\hline \multirow{6}{*}{ Japanese cedar } & \multirow[t]{2}{*}{ Sapwood } & A & $<0.1$ & $<0.1$ & $<0.1$ & 21.6 & 18.0 & 34.2 & 23.0 & 15.7 & 9.2 \\
\hline & & $\mathrm{B}$ & $<0.1$ & $<0.1$ & $<0.1$ & 16.9 & 3.3 & 10.5 & 4.3 & 14.9 & 2.6 \\
\hline & \multirow[t]{2}{*}{ Transition zone } & A & $<0.1$ & $<0.1$ & $<0.1$ & 79.8 & 68.7 & 109.2 & 123.9 & 201.6 & 156.4 \\
\hline & & $\mathrm{B}$ & $<0.1$ & $<0.1$ & $<0.1$ & 103.5 & 74.0 & 61.7 & 5.9 & 121.9 & 129.2 \\
\hline & \multirow[t]{2}{*}{ Heartwood } & A & $<0.1$ & $<0.1$ & $<0.1$ & 435.2 & 5.6 & 438.4 & 15.9 & 429.9 & 15.2 \\
\hline & & $\mathrm{B}$ & $<0.1$ & $<0.1$ & $<0.1$ & 324.2 & 8.4 & 367.0 & 6.7 & 405.9 & 25.1 \\
\hline \multirow[t]{4}{*}{ Japanese cypress } & \multirow[t]{2}{*}{ Sapwood } & $\mathrm{C}$ & $<0.1$ & $<0.1$ & $<0.1$ & 21.4 & 4.9 & 62.4 & 57.1 & 48.4 & 11.5 \\
\hline & & $\mathrm{D}$ & $<0.1$ & $<0.1$ & $<0.1$ & 142.5 & 118.3 & 234.1 & 119.8 & 98.2 & 50.8 \\
\hline & \multirow[t]{2}{*}{ Heartwood } & $\mathrm{C}$ & $<0.1$ & $<0.1$ & $<0.1$ & 225.2 & 13.2 & 238.6 & 21.7 & 315.4 & 27.8 \\
\hline & & $\mathrm{D}$ & $<0.1$ & $<0.1$ & $<0.1$ & 193.3 & 21.5 & 227.7 & 22.0 & 238.4 & 21.5 \\
\hline
\end{tabular}

${ }^{\text {a }} n=3$

b The value below the determination limit

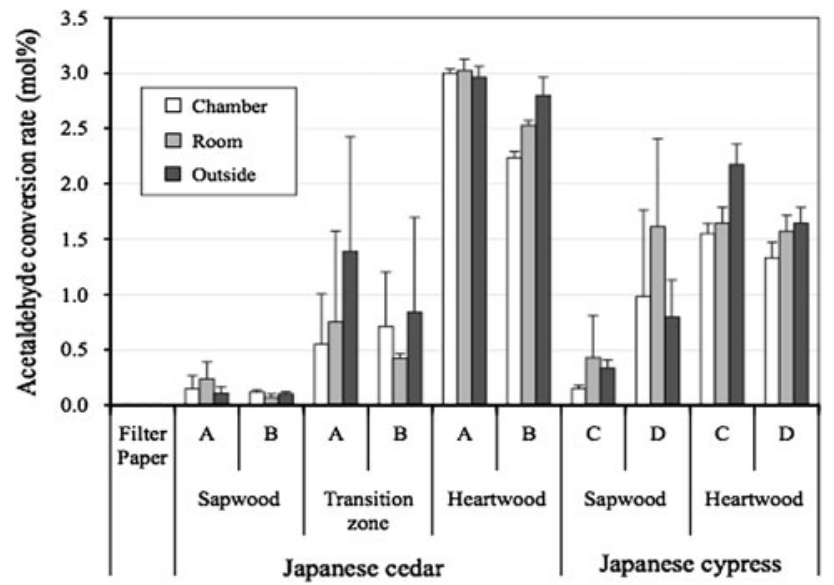

Fig. 2 Average value of acetaldehyde conversion rate (mol\%) in the syringe after $24 \mathrm{~h}$ at $30^{\circ} \mathrm{C}(n=3)$. Acetaldehyde conversion rate $(\mathrm{mol} \%)=$ detected acetaldehyde $(\mathrm{mol}) /$ added ethanol $(\mathrm{mol}) \times 100$

The acetaldehyde emission from the Japanese cedar transition zone is ranked midway between those from sapwood and heartwood. On the contrary, the control filter paper showed no acetaldehyde emission, even in the ethanol addition series, which means the ethanol oxidation did not occur on filter paper but on wood. In other words, the wood may have $\mathrm{ADH}$ or bacteria containing $\mathrm{ADH}$ somewhere in its tissue, and may allow the ethanol to contact the ADH, facilitating enzymatic oxidation, which seemed to function more in heartwood than in sapwood.

According to the previous papers [13-17], the amount of $\mathrm{ADH}$ enzyme in a living tree was reported more in sapwood, especially in the cambium, than in heartwood, because the living cell is located in sapwood. If acetaldehyde emission from wood is attributed to ethanol oxidation by ADH enzymes, the results obtained in the experiment would contradict the existence distribution of the enzyme in the living tree. However, it is possible that the enzymatic function in the living tree could change after harvesting depending on the storage condition. Therefore, we investigated the effects of storage site of wood on acetaldehyde emissions in the next section.

\section{Influence of storage site on acetaldehyde emission}

If $\mathrm{ADH}$ exists everywhere in the air, it may easily attach to the wood surface from the outside after cutting the sample due to microbial contamination. Therefore, we investigated the influence of storage site on acetaldehyde emissions by the addition of ethanol. Outside and room conditioning may also allow airborne bacteria to attach to the wood samples. Regarding chamber conditioning, however, as only clean air is provided into the chamber, the possibility of microbiological attachment from the open air should be low. The chamber was completely controlled at a constant condition of $28^{\circ} \mathrm{C}$ and $50 \%$ relative humidity throughout the conditioning period. Constant ambient conditions were also maintained for the room storage, with a temperature around $28^{\circ} \mathrm{C}$ and relative humidity between 50 and $70 \%$ as shown in Fig. 3a. The outside storage, conversely, saw changes in the condition of both temperature and humidity peak, depending on the weather shown in Fig. $3 b$. 
As shown in Fig. 2, the cedar A transition, the cedar B heartwood, the cypress $C$ heartwood and cypress D heartwood showed similar orders in terms of storage-place dependency: outside $>$ room $>$ chamber. This might be the result of microbial adherence from each environmental air. However, no clear difference in storage site was observed in the acetaldehyde conversion rate of the other samples, making it difficult to conclude a relationship between storage condition related to the potential for microbial attachment and acetaldehyde emission in the present study. Yoshida et al. [19] reported that the ADH gene, belonging to the short-chain dehydrogenase/

(a)

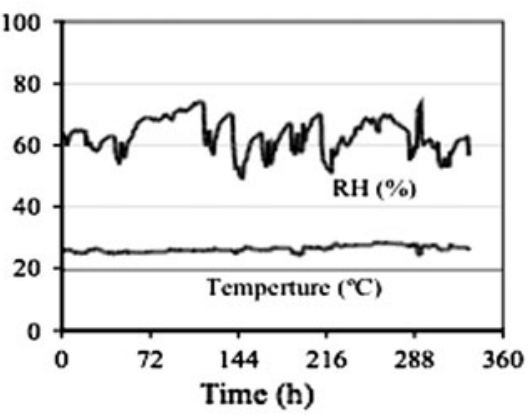

(b) 100

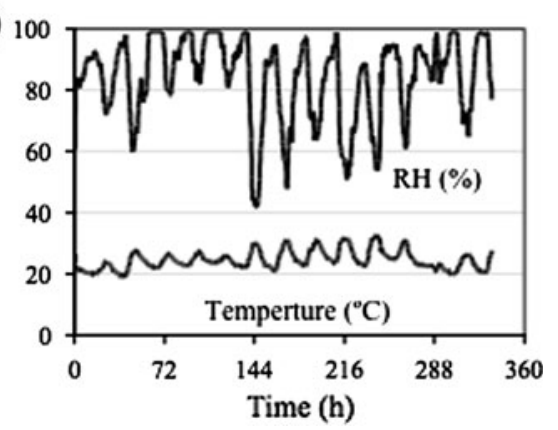

Fig. 3 Temperature and relative humidity $(R H)$ of indoor room (a) and outside (b) during conditioning period

Table 2 The effect of heating treatment on the amount of acetaldehyde in syringes containing Japanese cedar specimens

\begin{tabular}{|c|c|c|c|c|c|}
\hline \multirow{3}{*}{$\begin{array}{l}\text { Drying } \\
\text { temperature }\left({ }^{\circ} \mathrm{C}\right)\end{array}$} & \multirow{3}{*}{$\begin{array}{l}\text { Drying } \\
\text { time }\end{array}$} & \multirow[t]{3}{*}{ Parts } & \multicolumn{3}{|c|}{ Acetaldehyde $(\mu \mathrm{g})^{\mathrm{a}}$} \\
\hline & & & \multirow{2}{*}{$\begin{array}{l}\text { Control } \\
\text { Avg }\end{array}$} & \multicolumn{2}{|c|}{$\begin{array}{l}\text { Ethanol } \\
\text { addition }\end{array}$} \\
\hline & & & & Avg & SD \\
\hline \multirow[t]{2}{*}{28} & \multirow[t]{2}{*}{2 weeks } & Sapwood & $<0.3^{\mathrm{b}}$ & 19.2 & 11.9 \\
\hline & & Heartwood & $<0.3$ & 379.7 & 61.1 \\
\hline \multirow[t]{2}{*}{90} & \multirow[t]{2}{*}{$50 \mathrm{~min}$} & Sapwood & $<0.3$ & 0.6 & 0.9 \\
\hline & & Heartwood & $<0.3$ & 1.0 & 0.7 \\
\hline \multirow[t]{2}{*}{90} & \multirow[t]{2}{*}{$90 \min$} & Sapwood & $<0.3$ & $<0.3$ & - \\
\hline & & Heartwood & $<0.3$ & $<0.3$ & - \\
\hline
\end{tabular}

${ }^{a} n=5-6$

b The value below the determination limit reductase, of Japanese cedar sapwood was expressed 10 days after the storage term indoors and at room temperature after harvesting. Although it is unclear whether the $\mathrm{ADH}$ is derived from the inside of the wood and/or the outside, at least it can be said that the activity of $\mathrm{ADH}$ has changed during conditioning after harvesting.

Effects of heating on acetaldehyde emission

The effect of heating on acetaldehyde emission is shown in Table 2. It was clear that acetaldehyde was emitted only when ethanol was added. Acetaldehyde emission was also higher in heartwood than sapwood, as well as described above. Table 2 also shows that specimens dried at $90^{\circ} \mathrm{C}$ emitted less acetaldehyde than those dried at $28^{\circ} \mathrm{C}$. Moreover, extending the drying time from 50 to $90 \mathrm{~min}$ at $90^{\circ} \mathrm{C}$ also lowered acetaldehyde emission from wood. These results suggested that acetaldehyde emission from Japanese cedar through the reaction with ethanol can be lowered by heating wood. One possible reason for the decrease of acetaldehyde emission is the deactivation of the ADH enzyme by heating. The course of wood processing after harvest may also affect the $\mathrm{ADH}$ activation.

\section{Effects of conditioning and sterilization of wood}

Although the ADH adherence to wood from the outside was unclear, there was a possibility of $\mathrm{ADH}$ originally existing in wood. Therefore, we prepared heartwood samples from a freshly harvested cedar tree to reflect its native state as green wood. Air-dried cedar heartwood samples were also used to compare to the green cedar heartwood. In addition, sterilization of the heartwood samples was performed to clarify the ADH activity.

Table 3 shows the amount of acetaldehyde production in the syringe for the green and air-dried wood samples. Initially, it was reconfirmed that no acetaldehyde could be produced without ethanol as we reported before [11]. In the ethanol addition series, however, it was obvious that the autoclave sterilization treatment completely inhibited the oxidation of ethanol. Figure 4 shows the average acetaldehyde conversion rate for the ethanol addition series, the values for which were calculated from the data shown in Table 3. In the green cedar heartwood control, the ethanol-added samples showed less than $2 \mathrm{~mol} \%$ of the acetaldehyde conversion rate and likewise the EOG sterilization treatment of green wood samples. That means EOG of ambient temperature sterilization treatment had no work for acetaldehyde emission. Autoclave sterilization of green wood samples completely inhibited the conversion effect. Conversely, the air-dried wood control samples showed a conversion rate of around $5 \mathrm{~mol} \%$, more than double the values of the green wood control samples. 
Table 3 The effects of conditioning of wood and sterilization on the average value of acetaldehyde in the air of syringe at $30^{\circ} \mathrm{C}$ for $24 \mathrm{~h}$ after setting

\begin{tabular}{|c|c|c|c|c|c|c|c|c|c|c|c|c|c|}
\hline \multirow[t]{4}{*}{ Conditioning } & \multirow[t]{4}{*}{ Sample } & \multicolumn{12}{|c|}{ Acetaldehyde $(\mu \mathrm{g})^{\mathrm{a}}$} \\
\hline & & \multicolumn{4}{|c|}{ Control } & \multicolumn{4}{|l|}{ EOG } & \multicolumn{4}{|c|}{ Autoclave } \\
\hline & & \multicolumn{2}{|c|}{ Control } & \multicolumn{2}{|c|}{ Ethanol addition } & \multicolumn{2}{|c|}{ Control } & \multicolumn{2}{|c|}{ Ethanol addition } & \multicolumn{2}{|c|}{ Control } & \multicolumn{2}{|c|}{ Ethanol addition } \\
\hline & & Avg & SD & Avg & SD & Avg & SD & Avg & SD & Avg & SD & Avg & SD \\
\hline Blank & - & $<0.2^{\mathrm{b}}$ & - & $<0.2$ & - & - & - & - & - & - & - & - & - \\
\hline \multirow[t]{3}{*}{ Green } & Cedar E & $<0.4^{\mathrm{c}}$ & - & 142.9 & 64.1 & $<0.4$ & - & 261.9 & 134.8 & $<0.4$ & - & $<0.4$ & - \\
\hline & Cedar F & 0.9 & 0.1 & 212.0 & 45.0 & $<0.4$ & - & 293.0 & 71.9 & $<0.4$ & - & $<0.4$ & - \\
\hline & Cedar G & $<0.2$ & - & 271.8 & 90.5 & $<0.4$ & - & 214.5 & 115.5 & $<0.4$ & - & $<0.4$ & - \\
\hline \multirow[t]{3}{*}{ Air dried } & Cedar E & $<0.2$ & - & 677.6 & 159.7 & $<0.2$ & - & 35.5 & 10.0 & $<0.2$ & - & $<0.2$ & - \\
\hline & Cedar F & $<0.2$ & - & 782.5 & 133.5 & $<0.2$ & - & 86.8 & 41.5 & $<0.2$ & - & $<0.2$ & - \\
\hline & Cedar G & 0.8 & 1.1 & 789.6 & 81.0 & 0.6 & 1.3 & 84.4 & 41.7 & 0.9 & 1.7 & $<0.2$ & - \\
\hline
\end{tabular}

$E O G$ ethylene oxide gas

a $n=5$

$\mathrm{b}, \mathrm{c}$ The values below the determination limits depending on the lot ID of DNPH cartridge

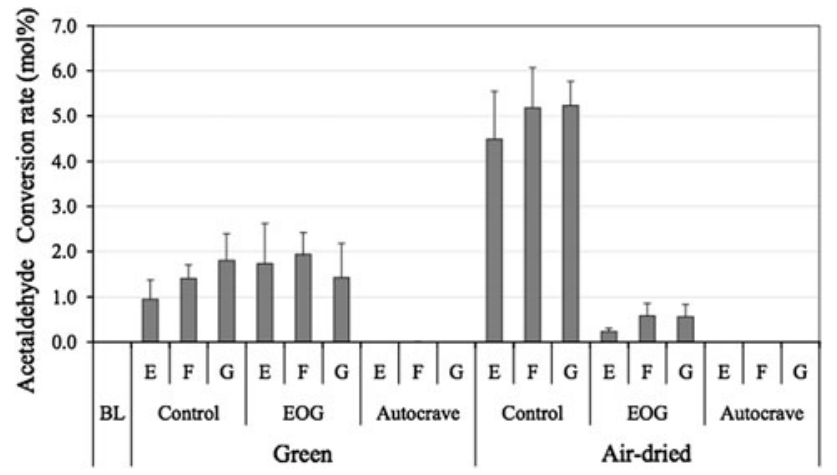

Fig. 4 The effect of conditioning and sterilization method for wood on acetaldehyde conversion rate $(\mathrm{mol} \%)$ in the ethanol addition series $(n=5)$

The EOG sterilization treatment of the air-dried wood samples showed less than $0.5 \mathrm{~mol} \%$ and inhibited most of the conversion effects by ethanol oxidation compared to the green wood samples. The autoclave sterilization of the air-dried wood samples inhibited the conversion effect completely, as well as that of the green wood samples. From the results, the acetaldehyde emission from the green wood samples with no treatment was probably caused by pre-existing $\mathrm{ADH}$ in the heartwood in the form of a native enzyme.

Ethylene oxide gas is a well-known chemical sterilization method used to kill all viruses, bacteria and fungi [20]. In this study, however, the EOG sterilization had no inhibitory effect on acetaldehyde production for green wood samples, which means that original ADH enzymes survived and retained their enzymatic activity; even after EOG sterilization treatment had been completed. Ethylene oxide gas treatment at ambient temperature and under a high moisture environment could not be implemented for an $\mathrm{ADH}$ inactivation. In contrast, autoclave sterilization is a typical heat sterilization method with high temperature and steam [20]. The treatment kills all microorganisms and enzymes, even under conditions of high moisture. The results of autoclave treatment suggested that $\mathrm{ADH}$ completely lost the enzymatic activity of oxidation conversion due to heat and correlated with those of the higher temperatures heating of $90^{\circ} \mathrm{C}$ in the former section, showing no acetaldehyde production by the addition of ethanol for the same reason.

Therefore, acetaldehyde production of the air-dried wood samples with no sterilization treatment could be attributed to the sum of the ethanol oxidation by the original $\mathrm{ADH}$, while an additional conversion action by a secondary ADH might be attached to a wood surface from the outside during the air-drying process. EOG sterilization for air-dried wood samples would be inhibited by most of the additional secondary ADH effect. We assumed that the difference of acetaldehyde emission between the control and EOG treatment samples was due to the secondary ADH via externally attached microorganisms. The microorganism was killed by EOG sterilization, whereupon the contained $\mathrm{ADH}$ may also be damaged with their host simultaneously. If the hypothesis is true, the secondary ADH effect is much higher than the original ADH effect.

\section{Conclusions}

The mechanism of acetaldehyde emission from wood induced by the addition of ethanol was investigated. The ethanol conversion reaction into acetaldehyde with wood 
progressed largely in heartwood than in the sapwood in both Japanese cedar and Japanese cypress samples. The autoclave sterilization of wood completely inhibited the conversion reaction, while the EOG sterilization of wood could not inhibit the conversion reaction in the green wood samples. Based on all results, we can conclude that the conversion reaction is attributable to ethanol oxidation via ADH enzymatic metabolism. Original ADH was considered to exist in wood, especially in heartwood parts. Another possibility could be related to a microorganism containing ADH enzymes, which may come from outside and attach to a wood surface after cutting the wood in the open air.

Acknowledgments This work was supported by Grant-in-Aid for Scientific Research No. 18580171 from the Ministry of Education, Culture, Sports, Science and Technology of Japan.

\section{References}

1. Nakanishi J, Shinohara N, Naya M (2007) Acetaldehyde, AIST risk assessment document series, vol 11. Maruzen, Tokyo (in Japanese)

2. International Programme on Chemical Safety (1995) Environmental health criteria. In: Acetaldehyde, vol 167. World Health Organization, Geneva

3. International Agency for Research on Cancer (IARC) (1999) Monographs on the Evaluation of Carcinogenic Risks to Humans, vol 71. IARC, Lyon, pp 319-335

4. Ministry of Health, Labour and Welfare (2002) Interim report of investigative commission for sick house (indoor air quality) problem. http://www.mhlw.go.jp/houdou/2002/02/h0208-3.html. Accessed 1 July 2011 (in Japanese)

5. Ministry of Land, Infrastructure and Transport (2004) Report of survey of indoor air in actual residences in 2003. http://www. chord.or.jp/tokei/pdf/h15_juutaku.pdf. Accessed 13 August 2011(in Japanese)

6. Gishi S (2003) Research on the quality of indoor air 2, indoor acetaldehyde concentration at each step of construction. In: Proceedings of the Timber Engineering Forum, vol 7, pp 96-99 (in Japanese)

7. Tamura A (2004) Aldehydes and VOC emission from solid wood. In: Forestry and Forest Products Research Institute (ed) Sick building and wood based materials Data book. Ringyo Kagaku Gijutsu Shinkosyo, Tokyo, pp 85-95 (in Japanese)

8. Matsuda S, Teramura A, Yagi S, Tamura Y, Takemura A, Ono H (2004) The amount of emissions of aldehydes and VOCs form various wood-based materials. Wood Ind 59:67-72 (in Japanese)

9. Yagi S, Matsuda S, Teramura A, Yoshida H (2004) Acetaldehyde concentration of indoor air in newly constructed wood-framed residential structures. Mokuzai Gakkaishi 50:83-90 (in Japanese)

10. Miyamoto K, Tohmura S, Inoue A (2004) Measurement of VOCs emissions from various wood-based materials by using JIS small chamber method. In: Proceedings of 4th European Wood Based Panel Symposium, (CDROM) No. 24, Hanover, Germany, pp $1-10$

11. Tohmura S, Miyamoto K, Inoue A (2005) Acetaldehyde emission from glued-laminated timber using phenol-resorcinol-formaldehyde resin adhesives with addition of ethanol. J Wood Sci 51(4):421-423

12. Kimmerer TW, MacDonald RC (1987) Acetaldehyde and ethanol biosynthesis in leaves of plants. Plant Physiol 84:1204-1209

13. Kimmerer TW, Stringer MA (1988) Alcohol dehydrogenase and ethanol in the stems of trees: evidence for anaerobic metabolism in the vascular cambium. Plant Physiol 87:693-697

14. Harry DE, Kimmerer TW (1991) Molecular genetics and physiology of alcohol dehydrogenase in woody plants. For Ecol Manag 43:251-272

15. Kreuzwieser J, Scheerer U, Rennenberg H (1999) Metabolic origin of acetaldehyde emitted by poplar (Populus tremula $\times$ P. alba) trees. J Exp Bot 50:757-765

16. Kreuzwieser J, Harren FJM, Laarhoven LJJ, Boamfa I, LintelHekkert S, Scheerer U, Hüglin C, Rennenberg H (2001) Acetaldehyde emission by the leaves of trees-correlation with physiological and environmental parameters. Physiol Plant 113:41-49

17. Karl T, Curtis AJ, Rosenstiel TN, Monson RK, Fall R (2002) Transient releases of acetaldehyde from tree leaves-products of a pyruvate overflow mechanism? Plant Cell Environ 25:1121-1131

18. Kurosaki Y, Kumagai K, Noguchi M, Yamamoto N, Mizukoshi A (2007) Production of acetaldehyde via sugi wood, inspective experiment of enzymatic reaction. In: Proceedings of Society of Indoor Environmental Japan 2007, Miyagi, pp 168-169 (in Japanese)

19. Yoshida K, Nishiguchi M, Futamura N, Nanjo T (2007) Expressed sequence tags from Cryptomeria japonica sapwood during the drying process. Tree Physiol 27:1-9

20. Haraguchi T (1985) Sterilization methods. In: Japan Wood Society (ed) Wood science experimental instruction, II. Chemistry. Chugai Sangyo Chosakai, Tokyo, pp 314-319 (in Japanese) 